\title{
ALEKSANDRA PISARSKA \\ Cooperative relations between public higher education institutions: the contextual nature of the process of their creation
}

Aleksandra Pisarska, Ph.D., Jan Kochanowski University in Kielce, Faculty of Law, Administration and Management,

Poland, ORCID: 0000-0002-8165-0691

\section{Introduction}

Polarization of views on the role of universities is evident both in the academic environment and in its surroundings. The main dilemma comes down to choosing between an entrepreneurial university, whose model was proposed by (Clark, 1998), and a research university, referring to the idea of van Humboldt (Leja, 2017, pp. 2-24). Currently, the concept of an entrepreneurial university is beginning to supplant the traditional university based on the Humboldtian model more and more. This is manifested in the focus on commercialization of research results, and at the same time in intensive cooperation between universities and the socio-economic environment (Sułkowski, 2017, pp. 173-188).

Thus, according to the researchers (Laredo, 2007, pp. 441-456; Montesinos et al., 2008, pp. 259-271), a modern university has to carry out a complex mission which consists of three coexisting dimensions. Therefore, it is expected from a university to:

- educate (first mission),

- conduct research (second mission),

- make positive social changes (third mission). 
In addition, in recent years a new phenomenon has appeared - the necessity of expanding this triad with the need for universities (key institutions of the higher education system) to establish cooperation relations with users of knowledge (often enterprises), and thus to be an active actor in the economic arena.

Implementation of each of these missions is related to creating, accumulating and disseminating knowledge (Berbegal-Mirabent, et al., 2015, pp. 1407-1413), the acquisition of which requires conducting research. These, in turn, involve the need to engage resources without a guarantee of success. Increasing costs of conducting research cause situations in which universities are often unable to provide an adequate (essential from the perspective of the specific character of research) access to research infrastructure and an appropriate level of their financing. Therefore, a university is required to have well-developed capabilities and resources to conduct research. For this reason, there is a growing need to recognize, understand and explain managing not only knowledge created within these entities, but also capabilities and resources essential for generating this knowledge (Numprasertchai and Igel, 2005, pp. 1173-1182). In order to organize, generate and disseminate knowledge effectively, higher education institutions develop their capacities to conduct research by establishing durable cooperative relations, which, in theory, should contribute to a more efficient use of resources available to the partners of such a relation (Rubiano, et al., 2015, pp. 28-45; D'Este and Patel, 2007, pp. 1295-1313; Franco and Pinho, 2019, pp. 62-69). Although a higher education institution can generate knowledge by acting in isolation, it can be however expected that owing to the synergy effects that can only be achieved in inter-university relations, the institution can do so in a more effective way. In addition, cooperation between universities - in the opinion of scientists - plays a key role in supporting the implementation of sustainable development practices (Pero et al., 2017, pp. 1- 25). In this context, stated that there is a global consensus recognizing cooperation of these entities as an important and indispensable (Leonard et al., 2012, pp. 238-247) instrument for development of the academic environment.

At the same time, little is known about cooperative relations among universities, as evidenced by the small number of publications on the subject. In literature, this issue is usually described from the perspective of creating and developing their partnership with enterprises (e.g. D'Este and Perkmann, 2011, pp. 316-339), (Franco and Haase, 2015, pp. 316-339), (Klofsten and Jones-Evans, 2000, pp. 299309). However, universities can develop effective forms cooperation not only with enterprises, public institutions or non-profit organizations, but also with other higher education institutions.

Cooperative relations between public higher education institutions: the contextual nature of the process of their creation 
The aim of this study is to recognize the external conditions for establishing inter-university cooperative relations (public higher education institutions with one another). These conditions are at the same time the context in which a cooperative relation is or is not established. The article points out that despite the fact that establishing such relations is intentional, the external conditions (context) and benefits resulting from adjusting to those conditions are of key importance for their creation.

Thus, the study fits into a continuously growing tendency to turn away from a positivist, individualistic or atomistic explanation of paradigms - and striving for a relational, contextual and systemic understanding - of phenomena occurring in public space.

Although the role of management sciences is to support the practice of management, one can get the impression that in the case of cooperation of universities, the practice is preceding the theory significantly. Therefore, in this article, due to the lack of terminology in the area of the theory of managing public organizations, the term "inter-university cooperative relations" has been proposed as the one signifying cooperation between organizations forming the higher education system, including universities and public higher education institutions that are not universities.

\section{The concept and essence of inter-university cooperation: towards recognizing the specificity of relations between universities}

Universities have always faced a variety of cultural, educational, organizational and legal challenges. Only a few decades ago, the university's main mission was to teach and develop basic research. It was only relatively recently that this set of activities was extended to include the transfer of knowledge (Feldman and Desrochers, 2003; Kirby, 2006, pp. 5-24), and now with the progressing change in the working optics in this area, universities have started to play an active role in promoting results of their research directly.

This change is not surprising, especially when taking into consideration the fact that universities by their very nature generate innovations in order to meet diverse social needs. However, it should be kept in mind that universities are complex organizations involving many communities with various, often conflicting, interests, for which economic benefits may not be the most important - they may not even be perceived at first glance. This may discourage a university from playing the role of an active actor in economic life. In this respect, (Feldman and Desrochers, 2003, pp. 5-24) noted that the responsibility for this situation 
can be partly attributed to the lack of incentives and motivations for economic activity that could potentially bring benefits to both the university and the local and regional environment. However, universities should be capable of reading those incentives as well as opportunities and, more importantly, they should be willing to react to them. Therefore, a university is expected to behave entrepreneurially, which means that with its activities it goes beyond its role resulting from creating and transferring knowledge. Hence, it becomes a leader in creating ideas, activities and entrepreneurial institutions (Audretsch, 2009, pp. 43-74). From this perspective, universities are the main actors playing an active role in promoting: learning, innovation, transfer of knowledge and entrepreneurship (Guerrero and Urbano, 2012, pp. 43-74).

By its very nature, an entrepreneurial university adapts to environmental changes (Clark, 1998). Therefore, it requires special management (Subotzky, 1999, pp. 401-440) focused on development in the following dimensions:

- internal, by developing entrepreneurial culture at all organizational levels (Kirby, 2006, pp. 599-603),

- external, aiming at developing cultural, social and economic environment in which it operates, through creation of new enterprises (Chrisman, et al., 1995, pp. 267-281) and/or commercialization of research results (Jacob, et al., 2003, pp. 1555-1568).

In this way, an entrepreneurial university is capable of creating innovations, recognizing and creating opportunities; acting as a team, accepting risks and providing intelligent responses to challenges (Guerrero, et al., 2014, pp. 415-434). In addition, it can make significant changes in its manner of organization, taking a more promising position at the start to act in the future (Clark, 1998).

In general, an entrepreneurial university provides its students, researchers and employees with an appropriate environment for exploring business activities. According to this perspective, the role of a university is much broader than simply facilitating the transfer of knowledge (Audretsch, 2009, pp. 245-254). In fact, an entrepreneurial university is obliged to simultaneously carry out the mission in the area of: teaching, conducting research and developing entrepreneurship that leads to positive social and, in the longer term, economic changes (Franco, et al., 2017, pp. 31-47). Owing to this, it can stimulate entrepreneurial behaviour and the spirit of innovation in the local and regional community (in the area of its impact) (Pawłowski, 2009, pp. 65-76).

The contribution of universities to local and regional development can also be understood in terms of teaching and strengthening formal and informal networks in order to achieve social, civic and cultural goals. Therefore, in order

Cooperative relations between public higher education institutions: the contextual nature of the process of their creation 
to be able to exert significant influence on local and regional development, universities cooperate. By engaging in relations, universities can provide mutual benefits, both through the better use of well-qualified human resources and the material potential of $R \& D$ units to the benefit of creating a wide range of innovations or improvements.

An entrepreneurial university can pursue its goals in isolation (autonomously) or it can cooperate with other public higher education institutions. Cooperation in the public sector to which public higher education institutions belong in Poland is commonly understood as "any joint activity of two or more organizations that aims to increase public value through their joint action and not in isolation" (Austen, 2018, pp. 24-66). It includes common standards and mutually beneficial contacts (Thomson and Perry, 2006, pp. 20-32) and aims to achieve common goals reached through sharing resources and partners' involvement (Dagnino, et al. 2008, pp. 3-7). With regard to public organizations, the issue of cooperation seems basically obvious. Relations of this kind are created by competitors, which is a typical situation for strategic alliances. As a result, the challenges related to cooperation focus on solving the dilemma of preserving autonomy when undertaking collective actions.

Based on the definition of (Austen, 2018, pp. 24-66), the cooperation of public entities (public higher education institutions in particular) is a coherent set of actions and processes taking place in relations among public sector organizations. Their establishment - according to (Franco, 2011, pp. 41-51) - is a strategic decision taken by at least two independent organizations which are willing and able to exchange and/or share resources in order to seek opportunities, the use of which will contribute to achieving mutual benefits, impossible to be achieved by each of the co-operators when acting separately. Therefore, cooperation in this sector is a process that occurs when two or more organizations undertake to implement mutually consistent goals. This opinion is strengthened by (Franco and Hasse, 2015, pp. 41-51) by their linking cooperation to the interaction in which organizations, while maintaining their independence, strive to achieve complementary or mutually consistent goals. Wilson and Hynes (2008, pp. 620-628) also point out that cooperation concerns organizations that are able to exchange and share capabilities and resources in order to create value and develop additional capabilities and resources. According to Hillebrand and Biemans (2003), the aim of cooperation is in principle to establish a competitive advantage in the long run. In turn, in the perspective of (Jonhson, 2017, pp. 37693781 ), cooperation can provide the basis for generating and sharing knowledge among members of cooperating organizations. 
According to Duysters et al. (1999, pp. 343-351) organizations cooperate when they feel insufficiency or lack of resources. (Haase and Franco, 2011, pp. 314336) have identified various premises underlying the search for a partner and establishing cooperative relations:

- sharing knowledge,

- achieving technological benefits,

- achieving economies of scale,

- increasing the competitiveness of an organization.

However, in order for a cooperative relation to last over time and to provide the parties with benefits, each party must strive to achieve the goals that have been jointly adopted (Dieke and Karamustafa, 2000, pp. 467-494). Similarly, Gemünden et al. (1996, pp. 449-462) concluded that organizations are joining forces to reach predetermined goals whose essence comes down to satisfying needs of the parties involved (Lewis, 1992, pp. 45-62).

Inter-university cooperation, as part of the concept of an entrepreneurial university, closely corresponds with particular dimensions of its mission. In the educational dimension, inter-university cooperation manifests itself in the organization of lectures conducted by scientists from cooperating universities or internships for students and researchers at these universities and joint study programs (Van Damme, 2001, pp. 415-441).

In the area of scientific research, inter-university cooperation can be developed through joint realization of scientific projects (ÓBrien, 1995, pp. 187-198), by sharing technical equipment (Tetrevova and Vlckova, 2018), consultations, joint conferences or co-creation of scientific publications (Carey et al, 2006, pp. 47-53; Stockman, 2011).

The above areas of cooperation are logically connected with the third mission of a university, the implementation of which can be observed through free provision of accommodations and recreational facilities for various types of socially important undertakings.

However, according to the researchers (Berbegal-Mirabent et al., 2015, pp. 14071413; Boardman and Corleyb, 2008, pp. 900-913; Guan and Liu, 2016, pp. 97-112), the common feature of establishing inter-university relations is generally the intention to promote cooperation among researchers. Thus, their main goal is to generate and transfer knowledge (Chataway and Wield, 2000, pp. 803-824; Guan and Liu, 2016, pp. 97-112; Sabharwal and Hu, 2013, pp. 1301-1311). Cooperating entities strive to stimulate research and publications as well as cooperation with other scientists and/or research centres outside the cooperative system. As a result, cooperation of universities has developed significantly in recent years,

Cooperative relations between public higher education institutions: the contextual nature of the process of their creation 
followed by intensified international cooperation between scientists and research centres (Czarnitzki, et al., 2015, pp. 131-146). To a large extent, innovations are the result of these relations between researchers (Jeong, et al., 2014, pp. 520-531).

Along with the progressing globalization of higher education and support of information technology, the need for cooperation is increasing. As a result, transfer of knowledge is becoming more frequent, more intense and it quickly flows between cooperating universities. This is executed through various means, in particular scientific papers, conferences and exchange of scientists (Teichler, 2004, pp. 5-26). However, it should be taken into consideration that the effectiveness of cooperative relations depends on the proper selection of its parties. Melin (2009, pp. 31-40) believes that their selection should be guided by the complementarity of capabilities and resources necessary to increase the competitiveness of both partners. Owing to their relation, the parties will be able to gain mutual access to them, which - for public universities - may prove to be a significant step on the way to overcome shortages in this area.

However, the choice of a co-operator for a university (public higher education institution) still entails a certain degree of risk, despite the fact that in the laws of many countries it is burdened with a number of rigors and criteria (Franco and Pinho, 2010, pp. 62-69). Traditionally, universities are known for their own organizational structure, the beginnings of which sometimes date back to the Middle Ages. However, today universities face European and global events that question their traditional form of functioning (Czarnitzki et al., 2015, pp. 131-146).

In response to globalization and the process of regional integration, universities have internationalized. The change of their strategy can be observed through the increase of international cooperation, consolidation processes in higher education systems (Beerkens and Derwende, 2007, pp. 61-79), mergers (Knight, 2011, pp. 221-240; Prem, 2014, pp. 658-672), alliances or virtual campuses (Knight, 2011, pp. 221-240).

Cooperation is considered to be a mechanism allowing universities to expand their current set of activities (Chapman, et al., 2014, pp. 619-637), including by accumulating the potential necessary to increase academic activity on an international scale. In these conditions, universities have begun to re-analyse their strategies to obtain or maintain competitive advantages (Larner, 2015, pp. 197-205). More than a decade ago, Numprasertchai and Igel (2005, pp. 11731182) have noticed that scientific research is not only a factor in generating new knowledge, and thus maintaining the competitive advantage of universities, but also a key determinant of establishing cooperative relations between these entities. 
According to Etzkowitz (2003, pp. 293-338), the most frequent reasons for cooperation include the implementation of joint ventures in the field of research in which the parties share their costs. In this sense, attention is paid to the mechanisms that enable universities to share resources, overcome resource shortages and increase their innovative capacity. Nevertheless, despite their increasing use, there are still some uncertainties about cooperation of universities, in particular regarding the motives, success factors, obstacles and benefits underlying such relations.

The presented arguments clearly indicate the contextual nature of the processes of cooperation between higher education institutions. It is the changes taking place in the environment that force them to face new challenges.

Recently in Poland it has been indicated that there is a need to consolidate capabilities and resources of public higher education institutions. Hence, the current legislation enumerates several forms in which this process should be executed.

\section{Cooperation of public universities in Poland: subjects and conditions for establishing relations}

In Poland, the higher education system is made up of entities (see table 1), which may - under legal regulations - cooperate in the field of education and scientific activity. This means that they can undertake joint activities to promote scientific achievements and implement joint ventures, and above all - research projects.

Table 1. Entities forming the higher education system

\begin{tabular}{l|l|l|l|l|l|l|l}
\hline \multicolumn{7}{c}{ Higher education system } \\
\hline $\begin{array}{l}\text { higher } \\
\text { education } \\
\text { institu- } \\
\text { tions }\end{array}$ & $\begin{array}{l}\text { federa- } \\
\text { tions of the } \\
\text { higher } \\
\text { educa- } \\
\text { tion and } \\
\text { science } \\
\text { system }\end{array}$ & $\begin{array}{l}\text { Polish } \\
\text { Acad- } \\
\text { emy of } \\
\text { Sciences }\end{array}$ & $\begin{array}{l}\text { science } \\
\text { institutes } \\
\text { of Polish } \\
\text { Academy } \\
\text { of Sci- } \\
\text { ences }\end{array}$ & $\begin{array}{l}\text { research } \\
\text { insti- } \\
\text { tutes }\end{array}$ & $\begin{array}{l}\text { interna- } \\
\text { tional } \\
\text { science } \\
\text { insti- } \\
\text { tutes }\end{array}$ & $\begin{array}{l}\text { Polish } \\
\text { Acad- } \\
\text { emy of } \\
\text { Learn- } \\
\text { ing }\end{array}$ & $\begin{array}{l}\text { 0ther enti- } \\
\text { ties running } \\
\text { mainly scientific } \\
\text { activity in an } \\
\text { autonomous } \\
\text { and continuous } \\
\text { manner }\end{array}$ \\
\hline
\end{tabular}

Source: elaboration based on the Law on Higher Education and Science'.

1 Law on Higher Education and Science of 20 July 2018, Journal of Laws 2018, item 1668.

Cooperative relations between public higher education institutions: the contextual nature of the process of their creation 
The most important, from the point of view of the subject taken up, are higher education institutions, which are organizations established under the conditions set out in the Law on Higher Education and Science. Their autonomy is an important feature bestowed on them by the legislator. This is an essential (but not sufficient) condition for realizing one of the key tasks set by the legislator for these entities, namely to prepare society to play an active role in economic, social and cultural development. The basic problem associated with fulfilling this role does not necessarily lie in the level of autonomy but in constraints of resources, especially financial ones.

One of the possible, and in the present legal conditions - even preferred, solutions in the field of supplementing a university's resource shortages includes joining with another entity, as a result of which a new higher education institution will be created. In this case, the participants of the merged entity lose their legal personality in favor of the new entity. Joining of entities may also be executed through incorporation of one or more units by another higher education institution, with the incorporating organization retaining its identity. Additionally, combining universities can be a support for undertaking restructuring activities leading to a more efficient and more effective implementation of the mission. This means changing the organizational structure that will be related to the consolidation process and management optimization (Sułkowski, 2017, pp. 173-188).

Therefore, according to the regulations of the Law on Higher Education and Science, combining of higher education institutions can be achieved by consolidation or incorporation (see table 2).

It is worth noting that incorporation may - but does not have to - be preceded by various types of cooperative relations (including informal relations at the individual level, i.e., for instance between scientists), which are a manifestation of strengthening the partnership by the parties. At the same time, the loss of identity may be an important limitation of incorporation, especially in the case of universities deeply rooted in the regional environment. On the other hand, developing good practices will contribute to the increased importance of strategic management and due diligence, which accompanies incorporation of higher education institution (Sułkowski, 2017, pp. 173-188).

In this situation, a federation constitutes the solution envisaged in Art. 165 of the Law on Higher Education and Science. A federation can be formed by public academic higher education institutions with:

- another public academic higher education institution or public academic higher education institutions, 
- research institute/research institutes,

- an institute of the Polish Academy of Sciences/institutes of the Polish Academy of Sciences,

- an institute of the Polish Academy of Sciences/scientific institutes of the Polish Academy of Sciences.

Table 2. Options of joining public higher education institutions

\begin{tabular}{|c|c|c|}
\hline \multicolumn{3}{|c|}{ Options of joining public higher education institutions } \\
\hline $\begin{array}{c}\text { Federations (co- } \\
\text { operation) }\end{array}$ & $\begin{array}{l}\text { Consolidations } \\
\text { (mergers) }\end{array}$ & Incorporations \\
\hline $\begin{array}{l}\text { A federation } \\
\text { can be cre- } \\
\text { ated by a public } \\
\text { academic higher } \\
\text { education institu- } \\
\text { tion with another } \\
\text { public academic } \\
\text { higher education } \\
\text { institution, a re- } \\
\text { search institute, } \\
\text { institute of the } \\
\text { Polish Academy } \\
\text { of Sciences or } \\
\text { an international } \\
\text { institute. }\end{array}$ & $\begin{array}{l}\text { Selected units of } \\
\text { the higher edu- } \\
\text { cation system } \\
\text { can be combined } \\
\text { with other } \\
\text { public higher } \\
\text { education insti- } \\
\text { tutions, research } \\
\text { institutes or } \\
\text { institutes of the } \\
\text { Polish Academy } \\
\text { of Sciences. }\end{array}$ & $\begin{array}{l}\text { Public higher education institutions can be joined through: } \\
\text { - incorporation: a public academic university is incorporat- } \\
\text { ed into a public higher education institution by a legal act; } \\
\text { - the minister competent for higher education and science, } \\
\text { in consultation with the minister supervising a university } \\
\text { or a research institute, after consulting the director or the } \\
\text { scientific council of a research institute, by a regulation, } \\
\text { incorporates a public vocational school or a research insti- } \\
\text { tute into a public higher education institution; } \\
\text { - the minister competent for higher education and science, } \\
\text { by a regulation, at the request of the President of the Pol- } \\
\text { ish Academy of Sciences or a director of an institute of } \\
\text { the Polish Academy of Sciences and after consulting the } \\
\text { faculty competent for the scientific specialty of the insti- } \\
\text { tute, incorporates the institute of the Polish Academy of } \\
\text { Sciences into a public higher education institution; } \\
\text { - a public higher education institution into which another } \\
\text { public higher education institution, a research institute } \\
\text { or a Polish Academy of Sciences institute has been incor- } \\
\text { porated, joins the rights and obligations of this higher } \\
\text { education institution or institute, including the rights and } \\
\text { obligations arising from administrative decisions. }\end{array}$ \\
\hline
\end{tabular}

Source: own elaboration based on the Law on Higher Education and Science

Public higher education institutions cannot participate in a federation together with non-public academic higher education institutions. A federation is created for the purpose of joint implementation of tasks in order to:

- conducting scientific activities,

- educating doctoral students, 
- conferring scientific degrees or degrees in the field of arts,

- commercialization of results of scientific activities and know-how related to these results.

In addition, parties to this relation may entrust a federation with the implementation of other tasks set out in the statute of a federation, excluding academic teaching. At the same time, when deciding to cooperate, entities are obliged to provide financial resources for the implementation of the abovementioned tasks and to cover any costs of functioning of a federation.

In addition, the parties involved in these relations must only pursue common goals, which clearly means the necessity to cease competitive activities. Thus, the legislator ruled out the possibility of coopetition of federated entities, that is simultaneous maintaining relations of cooperation and competition. This happened despite the fact that some researchers (Karwowska, Leja, 2018) suggest that it is the coopetition that corresponds best to the contemporary needs of the academic environment.

The main incentives to establish inter-university cooperation include additional funds to cover the costs of forming a federation. Higher education institutions that are willing to become a part of e federation can obtain a grant by submitting an application within a project, outside regular calls for proposals, entitled Supporting the consolidation processes of higher education institutions, implemented under the Operational Program Knowledge Education Development, co-financed by the European Social Fund.

The level of public higher education institutions' interest in creating federations is interesting. If they respond with their actions, it will mean that on the one hand they act reactively, and on the other, that the process of cooperation between public higher education institutions is initiated and implemented under the influence of the environment, and therefore is of a contextual character.

However, one fact cannot be ignored with all of the above, i.e. establishing this kind of a relation is a complex process with practically irreversible consequences. Therefore, it should be preceded by a professional diagnosis of the relational capability of public higher education institutions, which is necessary not only for establishment, but above all, long-term maintenance of a relation. And only long-term relations can provide its parties with real benefits owing to synergistic effects. 


\section{Conclusion}

Increasing competition, globalization and development of societies constitute challenges that public entities of the science and higher education sector must face by offering useful research results and education methods. This, in turn, forces constant improvement of the capabilities and resources being at their disposal (Leja 2011, pp. 16-19; Sułkowski 2017, p. 458).

Appreciating the importance of public higher education institutions in socioeconomic life, governments of many countries are making efforts to strengthen the development of these entities. These activities take various forms (programs of scientific and didactic excellence, strengthening internationalization through the implementation of international accreditations), including stimulating processes of consolidating public higher education institutions, which in essence are to improve the management of human capital remaining at their disposal (Sułkowski, 2017, p. 458). As a result, the policy conducted in many countries has already led to consolidating public universities, and hence to increasing the academic excellence of those universities, improving access to education (rationalization of the education network) and rationalizing education costs.

Changes that have been introduced in recent years in the area of higher education in Poland are the expression of the global wave of strengthening public entities in higher education systems. This wave was initiated nearly two decades ago. The activities carried out in this area, as it was done in other countries, are to strengthen public universities, giving them a chance to subsist in the scientific, educational and business dimensions.

One of the ways of consolidation includes establishing inter-university cooperative relations, which requires creating a favourable environment for this action. Such an environment, so it seems, is currently being created and the Law on Higher Education and Science, despite a number of imperfections, is certainly an important step in this direction. However, which model of consolidation will be chosen by Polish public higher education institutions cannot be determined from the current perspective. Certainly, some will choose the incorporation model, others will prefer forming a federation, which is essentially a cooperation that allows the existing partners to preserve their positions. Others - perhaps the most powerful ones - will remain independent.

In light of the findings made, it can therefore be assumed that the establishment of appropriate legal options for university consolidation will create a space which will be conducive to this process. Ultimately, however, its implementation will depend on the intensity of the impact of a number of efficiency determinants.

Cooperative relations between public higher education institutions: the contextual nature of the process of their creation 
It is the issues related to the expected improvement of results that will become crucial for initiating and, as a consequence, establishing various forms of cooperation as well as joining and incorporations.

Cooperation of higher education institutions is an area recognized to a very small extent, as evidenced by the small number of scientific publications on the subject. Hence, in empirical studies of cooperative relations between public higher education institutions, it is worth using (preceded by an intelligent adaptation) a rich amount of knowledge (including research methods) concerning this phenomenon relating to commercial organizations.

In addition, an important issue worth further exploration is how (assuming the existence of a positive context for the analyzed process) cooperative relations will be affected by the perspective of organizational closeness, and in particular what dimension (Klimas 2011, pp. 16-20) of this closeness (e.g. geographical, cultural, organizational) will be of key importance to establishing these relations.

\section{Summary}

Cooperative relations between public higher education institutions: the contextual nature of the process of their creation The aim of this study is to recognize the external conditions for establishing cooperative relations between public higher education institutions. At the same time, these conditions constitute the context in which a cooperative relation is or is not established. The article points out that establishing such relations is intentional. It is the external conditions (context) and benefits of adjusting to them that are of key importance for their creation and, in the long run, foe their maintenance. The study focuses on the possibilities of cooperation between public higher education institutions in the legal form of a federation. The study was based on the results of reviewing the literature and current legal acts regulating the higher education system in Poland.

Keywords: publichighereducation institutions, higher education system, cooperation.

\section{Streszczenie}

Relacje współdziałania pomiędzy publicznymi szkołami wyższymi: kontekstualna natura procesu ich tworzenia Celem opracowania jest rozpoznanie zewnętrznych uwarunkowań nawiązywania relacji współdziałania publicznych szkół 
wyższych między sobą. Uwarunkowania te stanowią zarazem kontekst $w$ jakim zostaje ustanowiona, bądź też nie relacja współdziałania. W artykule zwrócono uwagę, że nawiązywanie tego rodzaju relacji ma charakter intencjonalny. To warunki zewnętrzne (kontekst) i korzyści wynikające z dopasowania się do nich mają kluczowe znaczenie dla ich tworzenia a w dalszej perspektywie utrzymywania. $\mathrm{W}$ badani skoncentrowano się na możliwości współdziałania uczelni publicznych w przewidzianej prawem formie federacji. Badanie przeprowadzono $\mathrm{w}$ oparciu o wyniki przeglądu literatury oraz aktualnych aktów prawnych regulujących ustrój szkolnictwa wyższego w Polsce.

\section{Słowa}

kluczowe: $\quad$ publiczne szkoty wyższe, system szkolnictwa wyższego, wspótdziałanie.

JEL

Classification: I23; I28; L14

\section{References}

1. Audretsch, D.B. (2009). The entrepreneurial society, Journal of Technology Transfer, Vol. 34, No. 3, pp. 245-254.

2. Austen, A. (2018). In search of network sustainability: a multi-level perspective on the paradox of cooperation and competition in networks, Sustainability, Vol. 10, pp. 24-66.

3. Beerkens, E., Derwende, M. (2007). The paradox in international cooperation: Institutionally embedded universities in a global environment, Higher Education, Vol. 53, No. 1, pp.61-79.

4. Berbegal-Mirabent, J., Sánchez García, J.L., Ribeiro-Soriano, D.E. (2015). University-industry partnerships for the provision of R\&D services, Journal of Business Research, Vol. 68, No. 7, pp. 1407-1413.

5. Boardman, P.C., Corleyb, E.A. (2008). University research centers and the composition of research collaborations, Research Policy, Vol. 37, pp. 900913.

6. Carey, T.S., Howard, D.L., Goldmon, M., Roberson, J.T., Godley, P.A., Ammerman, A. (2006). Developing effective interuniversity partnerships and community-based research to address health disparities, Academic Medicine, Vol. 81, pp. 47-53.

7. Chapman, D.W., Pekol, A., Wilson, E. (2014). Cross-border university networks as a development strategy: Lessons from three university networks focused on emerging pandemic threats, International Review of Education, Vol.60, No. 5, pp.619-637.

Cooperative relations between public higher education institutions: the contextual nature of the process of their creation 
8. Chataway, J., Wield, D. (2000). Industrialization, innovation and development: What does knowledge management change? Journal of International Development, Vol. 12, pp. 803-824.

9. Chrisman, J., Hynes, T., Frase,r S. (1995). Faculty entrepreneurship and economic development: The case of the University of Calgary, Journal of Business Venturing, Vol. 10, pp. 267-281.

10. Clark, B.R. (1998). Creating entrepreneurial universities, organisational pathways of transformation. Oxford: Pergamon IAU Press.

11. Czarnitzki, D., Doherr, T., Hussinger, K., Schliessler, P., Toole, A.A. (2015). Knowledge creates markets: The influence of entrepreneurial support and patent rights on academic entrepreneurship, European Economic Review, Vol. 86, pp. 131-146.

12. D'Este, P., Patel, P. (2007). University-industry linkages in the UK: What are the factors underlying the variety of interactions with industry? Research Policy, Vol. 36, No. 9, pp. 1295-1313.

13. D'Este, P., Perkmann, M. (2011). Why do academics engage with industry? The entrepreneurial university and individual motivations, Journal of Technology Transfer, Vol. 36, No. 3, pp. 316-339.

14. Dagnino, G.B., Le Roy, F., Yami, S., Czakon, W. (2008). Strategie koopetycji - nowa forma dynamiki międzyorganizacyjnej? Przegląd Organizacji, No. 6, pp. 3-7.

15. Dieke, P.U., Karamustafa, K. (2000). Cooperative marketing in the accommodation subsector: southeastern mediterranean perspectives, Thunderbird International Business Review, Vol. 42, No. 4, pp. 467-494.

16. Duysters, G., Kok, G., Vaandrager, M. (1999). Crafting successful strategic technology partnerships, RED Management, Vol. 29, No. 4, pp. 343-351.

17. Etzkowitz, H. (2003), Innovation in innovation: The Triple Helix of university-industry-government relations, Social Science Information, Vol. 42, No. 3, pp. 293-338.

18. Feldman, M., Desrochers, P. (2003). Research universities and local economic development: Lessons from the history of the Johns Hopkins University. Industry E Innovation", Vol. 10, No. 1, pp. 5-24.

19. Franco, M., Haase, H. (2015). University-industry cooperation: Researchers' motivations and interaction channels, Journal of Engineering and Technology Management, Vol. 36, pp. 41-51.

20. Franco, M., Haase, H., Reis, A. (2017). Determinants of university cooperation networks as a mechanism for regional development: The case of Beira Interior (Portugal) [in:] M. Peris-Ortiz, J.J. Ferreira (eds.), Cooperative and networking strategies in small business, innovation, technology, and knowledge management, Springer International Publishing, Switzerland.

21. Franco, M., Pinho, C. (2019). A case study about cooperation between Uniwersity Research Centres: Knowledge, transfer perspective, Journal of Innovation \& Knowledge, Vol. 4, pp. 62-69. 
22. Gemünden, H.G., Ritter, T., Heydebreck, P. (1996). Network configuration and innovation success: an empirical analysis in German high-tech industries, International Journal of Research in Marketing", Vol. 13, No. 5, pp. 449-462.

23. Guan, J., Liu, N. (2016). Exploitative and exploratory innovations in knowledge network and collaboration network: A patent analysis in the technological field of nano-energy, Research Policy, Vol. 45, No. 1, pp. 97112.

24. Guerrero, M., Urbano, D. (2012). The development of an entrepreneurial university, Journal of Technology Transfer, Vol.37, No. 1, pp. 43-74.

25. Guerrero, M.,Urbano, D., Cunningham,J., Organ, D. (2014). Entrepreneurial universities in two European regions: A case study comparison, Journal of Technology Transfer, Vol. 39, pp. 415-434.

26. Haase, H., Franco, M. (2011). An exploratory study of the motives and perceived effectiveness of international cooperative alliances among SME, International Journal of Entrepreneurship and Innovation Management, Vol. 13, No. 3/4, pp. 314-336.

27. Hillebrand, B., Biemans, W.G. (2003). The relationship between internal and external cooperation: literature review and propositions, Journal of Business Research, Vol. 56, pp. 735-743.

28. Jacob, M., Lundqvist, M., Hellsmark, H. (2003). Entrepreneurial transformations in the Swedish University system: The case of Chalmers University of Technology, Research Policy, Vol. 32, pp. 1555-1568.

29. Jeong, S., Choi, J.Y., Kim, J.Y. (2014). On the drivers of international collaboration: The impact of informal communication, motivation, and research resources, Science and Public Policy, Vol. 41, No. 4, pp. 520-531.

30. Jonhson, M.P. (2017). Knowledge acquisition and development in sustainability- oriented small and medium-sized enterprises: exploring the practices, capabilities and cooperation, Journal of Cleaner Production, Vol. 142, pp. 3769-3781.

31. Karwowska, E., Leja, K. (2018). Czy społeczna odpowiedzialność uniwersytetu może być bardziej odpowiedzialna? Szanse wynikające z koopetycji uczelni, e-mentor, No. 3 .

32. Kirby, D.A. (2006). Creating entrepreneurial universities in the UK. Applying entrepreneurship theory in practice, Journal of Technology Transfer, Vol. 31, No. 5, pp. 599-603.

33. Klimas, P. (2011). Wymiary bliskości w sieciach innowacji. Przeglad Organizacji 4/2011, pp.16-20.

34. Klofsten, M.,Jones-Evans, D. (2000). Comparing academicentrepreneurship in Europe - The case of Sweden and Ireland, Small Business Economics, Vol. 14, No. 4, pp. 299-309.

35. Knight, J. (2011). Education hubs: A fad, a brand, an innovation? Journal of Studies in International Education, Vol. 15, No. 3, pp. 221-240.

Cooperative relations between public higher education institutions: the contextual nature of the process of their creation 
36. Laredo, P. (2007). Revisiting the third mission of universities: Toward a renewed categorization of university activities? Higher Education Policy, Vol. 20, No. 4, pp. 441-456.

37. Larner, W. (2015). Globalising knowledge networks: Universities, diaspora strategies, and academic intermediaries, Geoforum, Vol. 59, pp. 197-205.

38. Leja, K. (2017). Uniwersytet na rozdrożu, Studia $i$ Materiały Kolegium Zarzadzania i Finansów SGH, No. 155, pp. 9-24.

39. Leonard, K.M., Cosansa, C., Pakdil, F. (2012). Cooperation across cultures: an examination of the concept in 16 countries, International Journal of Intercultural Relations, Vol. 36, pp. 238-247.

40. Lewis, J. D., (1992). The new power of strategic alliances, Strategy and Leadership, Vol. 20, No. 5, pp. 45-62.

41. Melin, G. (2009). Pragmatism and self-organization research collaboration on the individual level, Research Policy, Vol. 29, pp. 31-40.

42. Montesinos, P., Carot, J.M., Martinez, J., Mora, F. (2008). Third mission ranking for world class universities: Beyond teaching and research, Higher Education in Europe, Vol. 33, No. 2-3, pp. 259-271.

43. Nave, A., Franco, M. (2019). University-Firm cooperation as a way to promote sustainability practices: A sustainable entrepreneurship perspective, Journal of Cleaner Production, Vol. 230, pp. 1188-1196.

44. Numprasertchai, S., Igel, B. (2005). Managing knowledge through collaboration: Multiple case studies of managing research in university laboratories in Thailand, Technovation, Vol. 25, No. 10, pp. 1173-1182.

45. ÓBrien K.M. (1995). Enhancing research training for counseling students: Interuniversity collaborative research teams, "Counselor Education and Supervision", Vol. 34, No 3, pp. 187-198.

46. Pawłowski, A. (2009). The sustainable development revolution, Problems of Sustainable Development, Vol. 4, No. 1, pp. 65-76.

47. Pero, M., Moretto, A., Bottani, E., Bigliardi, B. (2017). Environmental collaboration for sustainability in the construction industry: an exploratory study in Italy, Sustainability, Vol. 9, No. 1, pp. 1- 25.

48. Prem, E. (2014). Identifying international research cooperation capabilities in information and communication technologies, Science and Public Policy, Vol. 41, No. 5, pp. 658-672.

49. Rubiano, M., Rangel, P., Pacheco, P., Hernández, F. (2015). Research results transfer towards the productive sector via research collaboration in four Colombian public universities, Journal of Technology Management $\mathcal{E}$ Innovation, Vol. 10, No. 4, pp. 28-45.

50. Sabharwal, M., Hu, Q. (2013). Participation in university-based research centers: Is it helping or hurting researchers? Research Policy, Vol. 42, No. 6-7, pp. 1301-1311.

51. Stokman, F.N. (2011). The crucial role of cooperation and competition in social networks for science and technology indicators, conference paper ENID S\&T Coference Rome October 24. 


\section{Management \\ 2019}

Vol. 23, No. 2

52. Subotzky, G. (1999). Alternatives to the entrepreneurial university: New modes of knowledge production in community service programs, Higher Education, Vol. 38, No. 4, pp. 401-440.

53. Sułkowski, Ł. (2017). „Fuzjomania” akademicka. Czy Polskę czeka fala konsolidacji uniwersytetów? Nauka i Szkolnictwo Wyższe, No. 2, pp. 173188.

54. Sułkowski, Ł. (2017). Fuzje uczelni. Czy w szaleństwie jest metoda? PWN, Warszawa.

55. Teichler, U. (2004). The changing debate on internationalisation of higher education, Higher Education, Vol. 48, No. 1, pp. 5-26.

56. Tetrevova, L., Vlckova, V. (2018). Benefits, limitations and measures concerning the development of cooperation between higher education institutions and external entities, Tertiary Education and Management, www.tandfonline.com/eprint/QfNq9QZZwReUi5mt8wT7/full.

57. Thomson, A.M., Perry, J.L. (2006). Collaboration processes: Inside the black box, Public Administration Review, Vol. 66, pp. 20-32.

58. Wilson, J., Hynes, N. (2008). Co-evolution of firms and strategic alliances: theory and empirical evidence, Technological Forecasting Social Change, Vol. 76, No. 5, pp. 620-628.

59. Van Damme, D. (2001). Quality issues in the internationalisation of higher education, Higher Education, Vol. 41, No. 4, pp. 415-441. 